\title{
PLANT FIBER REINFORCED BIOCOMPOSITE: PROPERTIES AND APPLICATIONS
}

Melih Soner CELIKTAS*, Solar Energy Institute, Ege University, İzmir, melihsoner@gmail.com

(iDhttps://orcid.org/0000-0003-0597-5133)

Merve UYAN, Solar Energy Institute, Ege University, İzmir, merveuyn@gmail.com

(iDhttps://orcid.org/0000-0002-0852-1658)

Received: 16.05.2019, Accepted: 29.08.2019

*Corresponding author

Review Article

DOI: $10.22531 /$ muglajsci.566251

\begin{abstract}
There is a growing trend in replacing conventional polymer composites by renewable materials for various industrial applications. Polymer composites, in which at least one component is biobased or biodegradable, are called biocomposites. Plant fibers have recently been used in biocomposite products due to their highly unique properties such as electrical, mechanical, thermal and optical properties, as well as biodegradability. Another reason for the emerging interest in these biomaterials is the abundancy and low cost. In addition, the growing awareness of environmental issues around the world has led researchers and manufacturers to make efforts in the field of bio-composite materials. In this context, many studies have been carried out to design and implement engineering and technological applications by utilizing plant fibers together with various polymers. As a result of natural bio-source driven high-performance materials, significant achievements have been reported in material science. In this study, the use of various plant fibers to fabricate biocomposite materials, the effects of the type of fibers on mechanical properties and the structure of biocomposites in the production process have been discussed along with future trends of plant fiber reinforced composites.
\end{abstract}

Keywords: Plant fibers, Polymer composites, PFRC, Mechanical properties, Future trends.

\section{BİTKİ LİFİ İLE GÜÇLENDİRİLMIŞ BIYYOKOMPOZİTLER: ÖZELLİKLERİ VE UYGULAMALARI}

\begin{abstract}
Özet
Son yıllarda farklı endüstriyel uygulamalar için geleneksel polimer kompozitlerin yerine yenilenebilir kaynakların kullanımına olan ilgi artmaktadır. En az bir bileșen biyobazlı veya biyobozunur olan polimer kompozitlere biyokompozit adı verilmektedir. Son zamanlarda bitki liflerinin sahip oldukları mekanik, termal, optik ve biyobozunurluk gibi benzersiz özellikleri sebebiyle biyokompozit ürünlerdekullanılmaktadır. Bu malzemelere olan yüksek ilginin bir diğer nedeni ise ucuz ve düşük ortam etkisine sahip olmalarıdır. Bitki liflerinin bol miktarda bulunabilirliği ve erişilebilirliği ortaya çıkan yeni ilginin ana nedenleridir. Doğal kaynaklardan oluşan yüksek performansh malzemeler sayesinde, malzeme bilimi alanındaki biyoteknolojide önemli kazanımlar dünya çapında artış göstermektedir. Bunlara ilaveten, dünyadaki çevre sorunlarına karșı artanfarkındalık, araștırmacıları ve üreticileri biyokompozit malzemeler alanında çaba göstermeye yöneltmektedir. Bu kapsamda farklı polimerlerle bitki liflerinin birlikte kullanıldığı mühendislik ve teknolojik uygulamalar için gerçekleştirilmiş birçok tasarım ve uyarlama çalışması bulunmaktadır. Doğal kaynağa dayalı yüksek performanslı malzemelerin bir sonucu olarak malzeme biliminde önemli başarımlar elde edilmiștir. Bu çalıșmada, çeşitli bitki liflerinin biyokompozit malzeme üretmek için kullanımı, lif türlerinin mekanik özellikler üzerindeki etkileri ve üretim sürecinde biyokompozitlerin yapısı ile bitki lif takviyeli güçlendirilmiş kompozitlerin gelecek eğilimleri üzerine tartışılmaktadır.
\end{abstract}

Anahtar Kelimeler: Bitkisel lifler, Polimer Kompozitler, PRFC, Mekanik özellikler, Gelecek eğilimleri.

Cite

Celiktas, M.S., Uyan, M., (2019). “Plant Fiber Reinforced Biocomposite: Properties And Applications”, Mugla Journal of Science and Technology, $5(2), 42-48$. 


\section{Introduction}

Intensive environmental pollution from plastics consumed causes a growing interest in non-biodegradable polymers usage. The benefits of these polymers have led to an increased tendency and the most important advantages in their use are ease of operation and cost reduction.

Furthermore, plant fibers are competitive with polymers due to their high strength / high modulus properties.

Plant fibers are easily found in nature. Therefore, their use is cheaper than synthetic fibers and they are more common in different fields. Developing mechanical properties is the best option for improving the application of PFRCs, making them suitable for use in a variety of applications.

Plant fibers have the potential to be used instead of glass fibers in composite materials due to their improved mechanical and competitive properties with glass fibers [1].

Scientists and technologists [2-7] have been continued researches on PFRCs recently because having better qualifications than commercial composites. There is increasing interest especially for whole of these good properties.

In the future most application areas on industries studies will be proceed to advance biodegradable materials. In addition, their ability to easily procure will also speed up research into the development of areas of use and the availability of other potential fibers.

In this study, the identification of other potential plant fibers and their specific properties are compared with each other. Many researches are being done to make them softer and though [4-7]. In addition to improving mechanical properties, thermal properties are tested under different conditions and comparisons are made with synthetic fiber-based composites [6-7].

This study aims to shows that plant fibre reinforced composite analysis and application and also aims to present current studies and developments for PFRCs. In addition this study shows that how the reinforcing materials were connected with the fibers and the methods used to improve the connections. Potential areas that can be used as a result of improving the properties of materials and how to expand these areas are discussed.

\section{Plant Fibers}

Plant fibers are classified with seed hair, bast fibers and leaf fibers bounding up with the resource. Some examples are cotton (seed hairs), ramie, jute, flax (bast fibers), sisal and abaca (leaf fibers). Jute, ramie, flax, and sisal are commonly used fibers for PFRCs. Due to prepare plant fiber reinforced composites, wood flour form of plant fibers were utilized. The properties of these fibers are shown in Table 1 [1].

\subsection{Classification of plant fibers}

Basic component of a cellulose molecule is dehydrated dglucose including three hydroxyl $(-\mathrm{OH})$ groups. Hydrogen bonds were founded in molecule as intermolecular and the other molecules. All of the plant fibers are hydrophilic because of these interactions. Synthetic fibers which are may be manufactured, via certain set of qualifications, however within plant fibers, that may be alterable noticeably. The cellulose of plant fiber comprises various inherent materials which are lignin and waxes.

The fibers are built of cellulose microfibrils are connected jointly with lignin. Somatic qualifications from plant fibers are actually impacted out of the chemical construction for example rating on polymerization, inducement and crystallinity affected with situations throughout progress for plants furthermore like extrusion ways utilized [2].

Table 1. Mechanical Properties of Natural Fibers

\begin{tabular}{lcccc} 
Fiber & $\begin{array}{c}\text { Specific } \\
\text { Gravity }\end{array}$ & $\begin{array}{c}\text { Tensile } \\
\text { Strength } \\
\text { (MPa) }\end{array}$ & $\begin{array}{c}\text { Modulus } \\
\text { (GPa) }\end{array}$ & $\begin{array}{c}\text { Specific } \\
\text { Modulus }\end{array}$ \\
\hline Jute & 1,3 & 393 & 55 & 38 \\
Sisal & 1,3 & 510 & 28 & 22 \\
Flax & 1,5 & 344 & 27 & 50 \\
Sun & & & & \\
hemp & 1,07 & 389 & 35 & 32 \\
Pine- & & & & \\
apple & 1,57 & 170 & 62 & 40 \\
$\begin{array}{l}\text { Glass } \\
\text { Fiber- }\end{array}$ & & & & \\
E & 2,5 & 3400 & 72 & 28 \\
\hline
\end{tabular}

A large quantity of versatility was in fiber qualifications are attached to the fibers are afflicted out of component from plant, attribute of plant and situation [2]. Various fibers have diverse extents and cross-sectional areas and also varied imperfections for example micropressings or pits or cracks. With distributing the microfibrils inside dissolvent as well accelerating below checked state, reaching an equivalent resilience utilizing plant fiber due to stimulate the cellulose than create that too stationary [3].

Table 2. The mechanical properties of some natural and man-made fibers

\begin{tabular}{ccccc} 
Fiber & $\begin{array}{r}\text { Density } \\
\left(\mathrm{g} / \mathrm{cm}^{3}\right)\end{array}$ & $\begin{array}{c}\text { Elonga- } \\
\text { tion } \\
(\%)\end{array}$ & $\begin{array}{c}\text { Tensile } \\
\text { strength } \\
(\mathrm{MPa})\end{array}$ & $\begin{array}{c}\text { Young's } \\
\text { modulus } \\
(\mathrm{GPa})\end{array}$ \\
\hline \multirow{2}{*}{ Cotton } & $1,5-1,6$ & $\begin{array}{c}3,0- \\
10,0\end{array}$ & $287-597$ & $5,5-12,6$ \\
& & & & \\
Jute & $1,3-1,46$ & $1,5-1,8$ & $393-800$ & $10,0-30,0$ \\
& & & $345-$ & \\
Flax & $1,4-1,5$ & $1,2-3,2$ & 1500 & $27,6-80$
\end{tabular}




$\begin{array}{ccccc}\text { Hemp } & 1,48 & 1,6 & 550-900 & 70 \\ \text { Ramie } & 1,5 & 2,0-3,8 & 220-938 & 44-128 \\ & & & & \\ \text { Sisal } & 1,33-1,5 & 2,0-1,4 & 400-700 & 9,0-38,0 \\ & & 15,0- & & \\ \text { Coir } & 1,2 & 30,0 & 175-220 & 4,0-6,0 \\ \begin{array}{c}\text { Softwood } \\ \text { kraft }\end{array} & 1,5 & - & 1000 & 40 \\ & & & 2000- & \\ \begin{array}{l}\text { E-glass } \\ \text { S-glass }\end{array} & 2,5 & 2,5-3,0 & 3500 & 70 \\ \begin{array}{c}\text { Aramide } \\ \text { (normal) }\end{array} & 1,4 & 3,3-3,7 & 3150 & 63,0-67,0 \\ \begin{array}{c}\text { Carbon } \\ \text { (stand- } \\ \text { ard) }\end{array} & 1,4 & 1,4-1,8 & 4000 & 240,0 \\ & & & & \\ \end{array}$

The plant fibers are qualified in diverse, predicaments and can be grouped in accordance with their origin, derivations of plant, which are shown in Figure 1.

\begin{tabular}{|l|l|l|}
\hline \multirow{2}{*}{} & $\begin{array}{l}\text { Bast/stem fi- } \\
\text { bres }\end{array}$ & $\begin{array}{l}\text { Abaca, Banana, Flax, Hemp, } \\
\text { Jute, Kenaf, Ramie, Soybean }\end{array}$ \\
\cline { 2 - 3 } & Leaf fibres & $\begin{array}{l}\text { Agave, Caroa, Harakeke, Hene- } \\
\text { quen, Palm, Sisal }\end{array}$ \\
\cline { 2 - 3 } $\begin{array}{c}\text { Plan } \\
\text { t } \\
\text { base } \\
\text { d fi- } \\
\text { bres }\end{array}$ & $\begin{array}{l}\text { Seed/fruit fi- } \\
\text { bres }\end{array}$ & $\begin{array}{l}\text { Stalk fibres } \\
\text { Borassus, Coir, Cotton, Milk } \\
\text { weed floss, Rice husk }\end{array}$ \\
\cline { 2 - 3 } & $\begin{array}{l}\text { Barley, Corn, Oat, Rice, Sugar- } \\
\text { cane, Sunflower, Wheat }\end{array}$ \\
\cline { 2 - 3 } & Grass/ reed & $\begin{array}{l}\text { Bamboo, Bagasse, Esparto, Sa- } \\
\text { bei, Phragmites, Communis, } \\
\text { Canary grass }\end{array}$ \\
\cline { 2 - 3 } & Wood fibres & Hard wood, Soft wood \\
\hline
\end{tabular}

Figure 1. Classification of plant fibers [1].

The cellulose microfibrils ordered in the cell walls have distinctive orientations, which vary bounding up with on the cell wall stage and with respect to the plant.

Major influence on the mechanical qualifications of the fibers of different plant types is orientation of the microfibrils. Result of its fibrillar construction and the large amounts of bonding, cellulose owns elevated tensile modulus [8].

\subsection{Properties of plant fibers}

Nowadays natural fibers have been used more than commercial fibers because of its qualifications which are renewability, unique power and weak density. The low cost of natural fibers and their sensitivity to the environment have been very effective in reducing the use of commercial fibers [2]. Plant fiber strengthen composites which names as PRFCs are distinguished according to their production methods, the kind of fiber used.

The features of PRFCs affect the structure of natural fibers, the connection between the polymer, the chemical construction in the fibers and their physical and chemical attributes. Most important step in improving the performance of PRFCs is to understand the mechanical properties of the plant fibers in depth. Table 2 includes the mechanical properties for some naturel and synthetic fibers.

Hemicellulose, cellulose, lignin and extractives are the ingredients of PRFCs and their concentrations depend on several factors which are location, dimension, fiber type etc. Table 3 is shown chemical composition of plant fibers which were selected [9].

\subsection{Plant fiber reinforced composites (PRFCs)}

The composition of a synthetic matrix and additive fibers shows raise to composites owning the best features of every constituent. The individual ingredients and on their interfacial convenience are affect the properties of composites. Different kinds of polymers were utilized as matrices for plant fiber composites. They extensively used in thermoset polymers. The polymers own different proximity against to the fiber has the variation in construction [8].

Thermoplastics provide efficacy than thermoset polymers. Low operation cost is the most important efficacy which supply with thermoplastic. Design resilience and simplify of molding combined components is the other profit. Polyethylene, polypropylene, polystyrene and poly (vinyl chloride) have been recognized as thermoplastic in most of the studies. For acquiring consistency in the product for thermoplastic, the distribution of the fibers in the composites is also an essential factor.

The composites are available for manufacturing in contrast to this a district which is the loading percentage. The fiber orientation in the composites is indiscriminate and with respect attribute variance is low than noticed in thermoset composites [1].

Thanks to actual fact that sphere in implementation, usage of plant fibers is developed remarkably and it is advanced particularly in aeronautics and manufacturing industries. Lignocellulosic materials are acquired by plants have drawn attention, for the production of compound principally upon composites. They are beginning to be wide exploited in the industry, manufacturing; biological systems, transport.

Crystallization kinetic studies on composites made of polyethylene and kenaf fiber were achieved which is taken out from the bast of the plant by Chen and Porter. Monitoring the moisture absorption and distension were used to determine the demonstration of flax fiber reinforced polypropylene furthermore measuring the consistent mechanical features of the samples at various humidity degrees [3]. 
The strength qualifications of PP/oil palm wood flour composites were investigated and the impacts of filler ingredients noticed by Zaini et al. The fiber/polymer interface was examined by the growth strategies on the surface alteration of cellulosic surfaces. Additionally a coating is applied that offer chemical connections among two phase due to develop the mechanical properties of composites. Impacts of immobilization ingredient on cellulosic fiber strengthened composites additionally the impact on qualifications were offered [3].

Küçükdoğan et al were utilized paper processing residues as filler due to produce high density polyethylene (HDPE) composite. This study was comprised standard test methods in order to determine the mechanical properties. They have concluded the tensile strength of paper industry mill residues filled HDPE composites were increased with 10-20\% compared to that HDPE [10].

Table 3. The composition of selected natural fibers

\begin{tabular}{cccccc} 
Temi- \\
Type of & Cellulose & Lignin & cellu- \\
fiber & $(\%)$ & $(\%)$ & $(\%)$ & Pec- & Ash \\
& tin(\%) & $(\%)$ \\
\hline
\end{tabular}

\section{A. Bast fiber}

$\begin{array}{cccccc}\text { Fiber flax } & 71 & 2,2 & 18,6-21 & 2,30 & \\ \text { Seed flax } & 43-47 & 21-23 & 24-26 & & 5 \\ \text { Kenaf } & 31-57 & 15-19 & 21,5-23 & & 2-5 \\ \text { Jute } & 45-71,5 & 12-26 & 13,6-21 & 0,2 & 0,5-2 \\ \text { Hemp } & 57-77 & 3,7-13 & 14-22,4 & 0,9 & 0,8 \\ \text { Ramie } & 68,6-91 & 0,6-0,7 & 5-16,7 & & \end{array}$

B.Core fiber

\begin{tabular}{|c|c|c|c|c|c|}
\hline Kenaf & $37-49$ & $15-21$ & $18-24$ & & $2-4$ \\
\hline Jute & $41-48$ & $21-24$ & $18-22$ & & 0,8 \\
\hline \multicolumn{6}{|c|}{ C.Leaf fiber } \\
\hline Abaca & $56-63$ & $7,0-9,0$ & $15-17$ & & 3 \\
\hline Sisal & $47-78$ & $7-11$ & $10-24$ & 10 & $0,6-1$ \\
\hline
\end{tabular}

The extruder ensures shear strength to solution polymer and simplify distribution of fibers within. Plant fibers are temperature susceptible and the operate temperature should be hold on under certain degree all of the reaction time, thus fulfillment the examination of shear and heat in the system very critical for composites.

Banana fiber and glass fiber composites were obtained by S. Joseph et al. Due to increase fiber filling the tensile, flexural and impact properties are rised. The tensile, flexural and impact properties of PALF and sisal based composites were investigated by S. Mishra et al. The examinations shown the properties were grown with mixing of a small quantity of glass fibers in these composites which names as hybrid impact [11].

Thermoplastic biocomposites were produced utilizing plant fiber and inorganic fiber with two different production method which were injection or compression moulding by Sain et al. According to results, compression moulding offers $50 \%$ higher impact strength [9].

Y. Li et al was combined sisal and glass fibers than hybrid composites were acquired. Hybrid composites have many advantages due to features of ingredients. The hybrid effect was observed in mechanical properties [11].

Sisal fiber was used as reinforced material by Jacob et.al, in this study they wondered how affect the $\mathrm{NaOH}$ pretreatment. Then they investigated with different ratios of $\mathrm{NaOH}$ and the result pointed out $4 \% \mathrm{NaOH}$ pretreatment causes maximum tensile strength [12].

Zhang et al. were studied with the mixtures of wood and bamboo fibers at different ratios by using $10 \%$ isocyanate resin. After that they have observed that mechanical properties raised by the increase of bamboo fibers ratio [13].

Gürüler et al., were utilized vine particles and wood particles in five various percentages were used as the raw material for small size sample panels $(56 \times 56 \times 2 \mathrm{~cm})$. The physical and mechanical properties of particleboards were investigated. Due to expose the properties with enforceable way Artificial neural networks (ANNs) were used to prediction. According to results, Artificial neural networks were efficient way to estimate the properties without time consuming. The results show particleboards were produced with using vine particles have high thickness swelling and water absorption values [14].

\subsection{Properties of PRFCs}

Features of PFRCs bound up with various factors such as volume fraction of the fibers, fiber appearance relation, fiber/matrix conglutination, tension transmission at the interface, and orientation [1]. Fiber selection with the inclusion of product time, along technique, appearance proportion, handling and fiber ingredient, matrix choice, interfacial resistance, fiber distribution, fiber orientation, composite producing method and porosity are the main factors impressing the properties of PFRCs. Some mechanical properties of PFRCs was shown in Table 4 [15].

Jute fiber as strengthen material for PP composites were utilized by Rahman et al. Jute fiber was processed with maleic acid and the results were observed. An increasing was shown on the tensile strength and flexural strength while increasing jute fiber loading. The other important result is the processed with maleic acid affect the tensile resistance [16].

Guillou et al were conducted a modeling and experimental study due to determine the thermal properties of kenaf fibers. Additionally, they aimed to give a base information the thermal property data for kenaf fibers. These data were improved kenaf fibers could be used additive material for composite materials according to their potential good thermal properties [17].

With the help of composite technology plant fibers which are the inexpensive goods have opportunity use in high perfor- 
mance device. The useful properties of two different materials were assembled with low manufacturing cost and also these materials could be beneficial, in different areas of engineering, elevated demonstration implementation.

Srubar III et al appraised mechanical properties of a biocomposite which have been fabricated by using oak wood flour as strengthen [18]. The whole level of crystallinity and decline in eventual tension and strain were decreased with the addition of oak. Mishra et al. were noticed mechanical attribute of natural/glass fibers strengthen hybrid composites and they were accomplished that combination of plant fibers with glass fiber improves the tensile, flexural and impact strength of the materials.

The mechanical features of kenaf fiber reinforced composites were improved by alkali treatment by Edeerozey et al. With this treatment the tensile resistance and Young's modulus were developed. In addition, using maleic anhydride polypropylene with kenaf fiber improves the tensile and flexural strength [9].

Table 4. Mechanical properties of PFRCs.

\begin{tabular}{|c|c|c|c|c|}
\hline Fiber & $\begin{array}{l}\text { Fiber } \\
\text { Treatment }\end{array}$ & Matrix & \begin{tabular}{|l} 
Tensile \\
Strength \\
( MPa)
\end{tabular} & $\begin{array}{l}\text { Elastic } \\
\text { Modulus } \\
\text { (GPa) }\end{array}$ \\
\hline Bagasse & Untreated & $\begin{array}{l}\text { Cardanol- } \\
\text { formal- } \\
\text { dehyde }\end{array}$ & 24.4 & 1.8 \\
\hline $\begin{array}{l}\text { Bagasse } \\
\text { powder }\end{array}$ & Untreated & $\begin{array}{l}\text { Poly } \\
\text { propylene }\end{array}$ & 35 & 2.0 \\
\hline Bagasse & Mechanical & $\begin{array}{l}\text { Poly } \\
\text { ethylene }\end{array}$ & $129 \pm 1$ & $440 \pm 6.1$ \\
\hline Bamboo & Alkali & $\begin{array}{l}\text { Poly } \\
\text { propylene }\end{array}$ & $40-51$ & $4.38-5.57$ \\
\hline Corn & Alkali & $\begin{array}{l}\text { Polylactic } \\
\text { Acid }\end{array}$ & $58-64$ & \\
\hline Kapok & Untreated & $\begin{array}{l}\text { Cassava } \\
\text { Starch }\end{array}$ & 3 & 25 \\
\hline Jute & $\mathrm{NaOH}$ & $\begin{array}{l}\text { Polyeth- } \\
\text { ylene }\end{array}$ & $\begin{array}{l}10.9 \pm 0 . \\
1\end{array}$ & $\begin{array}{l}0.25 \pm 0.0 \\
2\end{array}$ \\
\hline Flax & & $\begin{array}{l}\text { Poly } \\
\text { propylene }\end{array}$ & $29 \pm 1.5$ & $5 \pm 0.4$ \\
\hline Kenaf & & $\begin{array}{l}\text { Polylactic } \\
\text { Acid }\end{array}$ & $\begin{array}{l}61.1 \pm \\
1.3\end{array}$ & $3.8 \pm 0.1$ \\
\hline Cotton & Alkali & Epoxy & 45 & \\
\hline
\end{tabular}

With this treatment the tensile resistance and Young's modulus were developed. In addition using maleic anhydride polypropylene with kenaf fiber improves the tensile and flexural strength [9].
Different plant fibers and their effects for properties of PFRCs were studied by Wambua et al. With using kenaf fiber as a additive material for PP composites, the tensile modulus and eventual tensile stress were improved. And also the availability of other plant fibers which are sisal, hemp, coir, kenaf and jute were determined for using reinforcing materials. An increasing for the tensile durability and modulus were seen with rising fiber volume fraction [19].

Rising surface roughness causes better mechanical interlocking additionally cellulose on the fiber was increased with alkaline treatment. Alkaline treatment affect the mechanical behavior particularly on fiber strength and stiffness with permanently [20]. Van de Weyenberg et al. were observed the tensile durability and modulus properties for flax fiberepoxy composites were increased by alkaline treatment [21]. As a conclusion alkaline treatment have significant impact on mechanical attitude.

Effects of $\mathrm{NaOH}$ pretreatment on mechanical behavior for sisal fiber-reinforced polyester composite were investigated by Mishra et al. The results show that $5 \% \mathrm{NaOH}$ treatment for sisal fiber-strengthen polyester composite shows better tensile resistance than $10 \% \mathrm{NaOH}$ treatment. They considered that result was arised of damaged fiber at higher $\mathrm{NaOH}$ concentration. For this reason it was considered appropriate to work under optimum conditions [22].

\subsection{Industrial application on PRFCs}

Plant fibers were emphasized in industrial applications which utilize as filler materials [23]. PFRCs own substantial play a considerable act in reformative physic includes implants, sewing, contact lenses, thigh knuckles, vascular vaccination, injury bandage ingredients, medicine discharge stents and distinct alternative biomedical apparatus.

In polymer matrices; jute, flax, hemp and coir were evaluated as recruitment material for automotive implementations, structure and wrapping industries [24]. Plant fibers have a wide range of uses and range from body panels of cars to inside parts which are door and window panels.

In the automobile industry, PRFCs owns an increasing knowledge in marketing and their usage. Mechanical properties of PFRCs which referred to the tensile, flexural and impact properties. Next to these features; weariness, humidity sorption, corrosion properties are analyzed with conducting most of researchers. These studies were achieved due to demonstrate their compatibility in order to utilize in construction ingredients particle woods of diversified intensities, diameters, with flame and insect deprecation, absorptives, weavings, livestock feed, and fibers in new and appraised plastics.

PFRCs have many quantities which are very critical qualifications [25]. These qualifications which refer as recyclability, well thermal and sound lagging features, bio-degradability, inexpensive, presence, energy saving, $\mathrm{CO}_{2}$ segregation improved, decreased vehicle corrosion in manufacturing processes and decreased integumentary and respiratory damage. Accordingly researches on potential implementations of PFRCs in different fields continues.

Apart from mechanical properties, thermal properties are very essential for whole of the usage areas. TGA, HDT, 
DMA which are known as the thermal properties are also analyzed for PFRCs. All of the features were established to be connected upon fiber dimension and fiber gravity fraction. The request degree, though numerous work is to be completed regarding fiber manufacturing, non-linear behavior, fiber/matrix adhesion, fiber distribution into matrix, composite processing with optimized working factors due to evolve performance.

Recently researches show which the mechanical features of PFRCs are connect upon the decision of the interfacial territory. Therefore, the description of the interface is of major significance. The dirtiness of fiber superficies and improved the interfacial conglutination among fiber and matrix were increased with alkali treatment, additionally reduced the fiber pullout which enhanced the properties. Solidified process, catalyst and changing chemical concentrations, fiber gravity fraction, fiber dimension and fiber handling were affected the mechanical features of PFRCs. Improving the thermal decisiveness of these fibers is the real challenge for the researcher therefore which utilize with engineering polymers and upwards the benefit of whole of ingredients of PFRCs.

\section{Future trends of PRFCs}

The examinations for mechanical properties and also the other properties of PRFCs show that the usage of PFRCs is expected to increase in several applications in the next years. However, they have many good properties for industrial applications which continue a number of difficulties which need to be eliminated due to own computable features for PFRCs compare with synthetic fiber composites.

They are sensitive to moisture as well temperature due to their biodegradability. Decomposition of kept completely under control is very difficult because they are biodegradable. Their mechanical behaviors are non-linear for this reason their long term performance is poor and they are shown weak stroke durability. Numerous of these failings can be overcome if improved processing of plant fibers and their composites can be improved. Processing for PRFCs consumes more energy due to more processing requirements so there is still a question about their availability.

An improvement is expected in novel markets about PRFCs will become over resistant, dimensionally decisive, humidity and flame durable. Due to appreciate the impacts of fiber pretreatment processes and distinct solidified processes on the longtime accomplishment for PFRCs are needed further studies.

\section{Conclusion}

The chemical and structural composition of plant fibers affects the mechanical and physical properties of the fibers as well as the fiber type and growth conditions. According to the studies examined, interfacial adhesion between plant fibers and matrix has priority for the overall performance of biocomposites. Corrosion between the matrix and the fiber significantly affects the mechanical properties of the composites. In this study, the importance of the interface, the effect of different types of superficies alteration, the different matrix types used for composites and the success of PFRCs have been investigated in many research and articles. In order to improve the quality of PFRCs, physical and chemical exchange processes have been developed.

Biodegradability, cheapness, reduced concern intensity, high specific resistance properties easily established in plant fibers are among the advantages and there is an increasing demand for plant fibers due to the local availability of fibers as well. In the near future, PRFCs have the chance to find a permanent place in lots of implementation with both legal legislation and population growth are rising.

\section{Acknowlengments}

This study was supported by the scientific research coordinator of the Ege University with FGA-2018-20029 project number.

\section{References}

1. Saheb, DN. and Jog, JP., "Natural Fiber Polymer Composites: A Review", Advances in Polymer Technology, 18(4), 351-363, 1999.

2. Jose da Silva, E., Marques, ML., Velasco, FM., Junior, CF., Luzardo, FM., Tashima, MM., "A new treatment for coconut fibers to improve the properties of cementbased composites - Combined effect of natural latex/pozzolanic materials", Sustainable Materials and Technologies, 12, 44-51, 2017.

3. George, J., Sreekala, MS., Thomas, S., "A Review on Interface Modification and Characterization of Natural Fiber Reinforced Plastic Composites", Polymer Engineering and Science, 41(9), 1471-1485, 2001.

4. Hatakeyama, T., Hatakeyama, H., "Thermal Properties of Green Polymers and Biocomposites", Hot Topics in Thermal Analysis and Calorimetry, 4, 12-332, 2004.

5. Averous, L. , Digabel, FL., "Properties of biocomposites based on lignocellulosic fillers", Carbohydrate Polymers, 66, 480-493, 2006.

6. Jawaid, M., Khalil, A., Alattas, OM., "Woven hybrid biocomposites: Dynamic mechanical and thermal properties", Composites Part A Applied Science and Manufacturing, 43(2), 288-293, 2012.

7. Reddy, TRK., Kim, HJ., Park, JW., "Renewable Biocomposite Properties and their Applications", Composites from Renewable and Sustainable Material, 177, 2016.

8. Abdul Khalil, HPS., Bhat, AH., Ireana Yusra, AF., "Green composites from sustainable cellulose nanofibrils: A review", Carbohydrate Polymers, 87(2), 963-979, 2012.

9. Ramesh, M., Palanikumar, K., Reddy, KHC., "Plant fibre based bio-composites: Sustainable and renewable green materials", Renewable and Sustainable Energy Reviews, 79, 558-584, 2017.

10. Kucukdogan, N., Halis, S., Sutcu, M., Sarikanat, M., Seki, Y., Sever, K., "Investigation of mechanical properties of paper processing residue filled high density polyetylene (HDPE) composites", Pamukkale University Engineering College Journal of Engineering Sciences, 23(8), 949-953, 2017. 
11. Sanjay, MR., Yogesha, B., "Studies on Natural/Glass Fiber Reinforced Polymer Hybrid Composites: An Evolution", Materials Today: Proceedings, 4(2), 2739-2747, 2017.

12. Li, X., Lope, G., Tabil, L.G., Panigrahi, S., "Chemical Treatments of Natural Fiber for Use in Natural Fiber-Reinforced Composites: A Review", Journal of Polymer Environment, 15(1), 25-33, 2007.

13. Eroğlu, H., İstek, A., Usta, M., "Medium Density Fiberboard (MDF) Manufacturing from Wheat Straw (Triticum aestivum L.) And Straw Wood Mixture", Pamukkale University Engineering College Journal of Engineering Sciences, 7(2), 305-311, 2001.

14. Gürüler, H., Ballı, S., Yeniocak, M., Göktaş, O., Estimation the Properties of Particleboards on composite panels using artificial neural networks, Mugla Journal of Science and Technology, 1, 24-33, 2015.

15. Yıldızhan, Ş., Çalık, A., Özcanlı M., Serin H., "Bio-composite materials: a short review of recent trends, mechanical and chemical properties, and applications", European Mechanical Science, 2(3),83-91, 2018.

16. Rahman, R., Hasan, M., Huque, M., Islam, N., "Physico-mechanical Properties of Maleic Acid Post Treated Jute Fiber Reinforced Polypropylene Composites", Journal of Thermoplastic Composite Materials, 22(4), 365-381, 2009.

17. Guillou, J., Lavadiya, D.K., Munro, T., Fronk, T., Ban, H., "From lignocellulose to biocomposite: Multi-level modelling and experimental investigation of the thermal properties of kenaf fiber reinforced composites based on constituent materials", Applied Thermal Engineering, 128, 1372-1381, 2018.

18. Srubar, WV., Pilla, S., Wright, ZC., Ryan, CA., Greene, JP., Frank, CW., Billigton, SL., "Mechanisms and impact of fibre-matrix compatibilization techniques on the material characterization of $\mathrm{PHBV} / \mathrm{oak}$ wood flour engineered bio based composites", Composite Science Technology, 72(6), 708-715, 2012.

19. Wambua, P., Ivens J, Verpoest, I., 'Natural fibres: can they replace glass in fibre reinforced plastics", Composite Science Technology, 63(9), 1259-1264, 2003.

20. Jahn, A., Schroder, MW., Futing, M., Schenzel. K., Diepenbrock, W., "Characterization of alkali treated flax fibres by means of FT Raman spectroscopy and environmental scanning electron microscopy", Spectrochimica Acta Part A: Molecular and Biomolecular Spectroscopy, 58(10), 2271-2279, 2002.

21. Van de Weyenberg, I., Ivens, J., De Coster, A., Kino, B., Baetens, E., Vepoes, I., "Characterization of Filled Polyester", Composites Science Technology, 63, 1241-1272, 2003.

22. Mishra, S., Mohanty, AK., Drzal, LT., Misra, M., Parija, S., Nayak, SK., Tipathy, SS., "Studies on mechanical performance of biofibre/glass reinforced polyester hybrid composites", Composite Science and Technology, 63, 1377-1385, 2003.
23. Pothan, LA., Oommen, Z., Thomas, S., "Dynamic mechanical analysis of banana fibre reinforced polyester composites", Composite Science and Technology, 63, 283-93, 2003.

24. Puglia, D., Biagiotti, J., Kenny, JM., “A review on natural fibre based composites-Part II: application of natural reinforcements in composite materials for automotive industry", Journal of Natural Fibers, 1(3), 23-65, 2004.

25. Babu, RP., O'Connor, K., Seeram, R., "Current progress on bio-based polymers and their future trends", Progress in Biomaterials, 2(8), 1-16, 2013. 